\title{
Animal performance changes over 11 years after implementing a lucerne grazing system on Bog Roy Station
}

\author{
Derrick J. MOOT ${ }^{1 *}$, Peter V.A. ANDERSON ${ }^{2}$, Lisa J. ANDERSON ${ }^{3}$ and David K. ANDERSON ${ }^{3}$ \\ ${ }^{1}$ Lincoln University, Field Research Centre, PO Box 85084, Lincoln University 7647, Canterbury, New Zealand \\ 2780 New Renwick Road, Blenheim 7272, New Zealand \\ ${ }^{3}$ Bog Roy Station, Private Bag 3, Kurow, New Zealand \\ *Corresponding author: Derrick.Moot@lincoln.ac.nz
}

\begin{abstract}
In 2008, Bog Roy was run as a typical high-country station with merino ewes and lambs set stocked for long periods of the year, with 60 ha of lucerne grown for hay. Over the next 7 years, the lucerne and ryecorn areas increased by 30 ha per year. Total lamb meat weaned increased from 91 to $130 \mathrm{t}$ in the first three years direct feeding of lucerne commenced, which improved ewe and two-tooth performance at lambing ( $\%$ and survival). In the second phase, ewe numbers and preweaning lamb growth rates increased. Lambs were weaned earlier and ewes returned to higher pasture covers on hills, which improved their condition score and weights at mating and lambing. In 2016, a change from flood to pivot irrigation resulted in a further production increase to $160 \mathrm{t}$ weaned lamb. By 2018, the mixed age ewes had $141 \%$ lambing (to tailing), and pre-weaning lamb growth rates of over $270 \mathrm{~g} /$ $\mathrm{hd} / \mathrm{d}$ which allowed weaning after 80 days. The lamb weaned per ewe mated has increased from 25 to $37 \mathrm{~kg}$ over the decade despite increased feed demand from 900 more ewes. These animal performance indicators quantify the transformational change achieved through a focus on grazing and increasing the area of lucerne. This was followed by lucerne and red clover based pastures being established under pivots. The ability to record and quantify changes in stock performance has given the farmer confidence to trust and embrace the transformational change.
\end{abstract}

Keywords: alfalfa, Medicago sativa, lambing \%, scanning \%, StockCare $\AA$, tenure review, wool production

\section{Introduction}

High-country farming systems often have a short spring growing season, due to 90-120 days of winter followed by low summer rainfall and high evapotranspiration rates. These systems usually require large numbers of animals to be fed conserved feed in summer dry and winter cold conditions. As a result, lambs frequently grow slowly pre-weaning and are weaned as light weight store lambs of low value before the summer dry commences.
Changes in recommendations for lucerne (Medicago sativa) grazing management (Moot et al. 2003) have led to transformational change on some dryland farms (Avery et al. 2008). In 2008, the owners of Bog Roy Station (in the Upper Waitaki region) sought advice on how to adapt a lucerne grazing system to their extensive high-country farm. Their rationale for the change and the operational requirements undertaken were detailed by Anderson et al. (2014). These management changes have led to significant improvements in animal performance across the merino flock. The aim of this paper is to document and provide commentary on how the transformational change in animal performance was achieved.

\section{Materials and Methods \\ Pasture management changes}

Briefly, in 2008, the 2860-ha property had 60 ha of lucerne with half grazed and half conserved. The 100 ha of flood irrigated ryegrass (Lolium perenne) and tall fescue (Schedonorus phoenix) pastures were used each spring to finish overwintered lambs, and then closed up for baleage. From 2008 to 2015, the lucerne area was expanded by about 30 ha per year to reach 265 ha of dryland lucerne and lucerne/cocksfoot (Dactlyis glomerata) mixes. In 2015, flood irrigation using water from Lake Benmore was stopped and the water right was transferred to an area previously growing less than 2 t DM/ha/yr. This meant 2015 was effectively unirrigated until 68 ha of lucerne with prairie grass (Bromus willdenowii) was established under a pivot in 2016. A further 35 ha under that pivot was sown in 2018 when a second pivot was established with 107 ha of red (Trifolium pratense) and white (T. repens) clovers.

All pasture development followed a similar pattern. Ryecorn (Secale cerale) crops were used for 2 years to break in low-production, poor-quality grass-dominant pastures before direct drilling lucerne. The ryecorn is now an integral part of the winter feed and this has led to a reduction in the amount of lucerne needed for conserved feed. The main management changes involved learning how to rotationally graze large mobs of ewes and lambs on lucerne. This started once lambs were about $2-3$ weeks of age and mobs were drifted off 


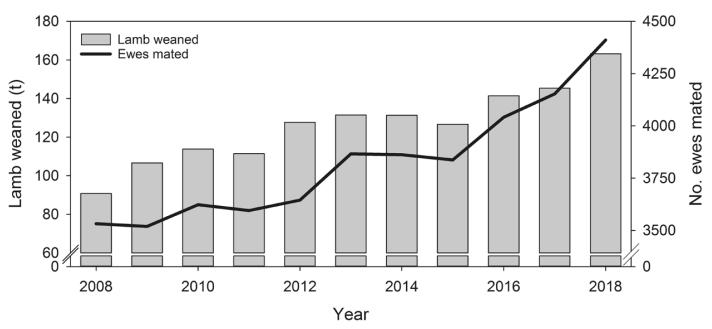

Figure 1 Changes in lamb weaned (t/yr) and number of ewes mated at Bog Roy Station in the Mackenzie District from 2008 (pre-development) to 2018.

hills to start a six paddock lucerne rotation. As the area of lucerne expanded across most of the easier contour area, there was also a need to learn how to lamb on some areas of lucerne and start rotational grazing earlier.

\section{Animal performance data}

The key flock performance and financial changes have been documented since 2012 using the flock recording programme StockCare ${ }^{\circledR}$. Data prior to this are from on-farm records of wool and meat production. To determine the property's ewe flock performance on an annual basis, StockCare ${ }^{\circledR}$ utilises the weight $(\mathrm{kg})$ of lamb weaned per ewe mated. The inputs required are accurate tallies of the number of lambs weaned and their weaning weights, as the ultimate result of lambing percentage and lamb growth rate to weaning. What drives the ewe flock performance is their management. The emphasis is to monitor and measure how the ewes are fed throughout the year by weighing and condition scoring a minimum of 50 randomly selected ewes per mob at set times. These are weaning, one month pre-mating, mating, ram removal, scanning, and at set stocking prior to lambing. Lambing mobs are also condition scored at tailing/docking time. The condition scoring over 11 years was undertaken by four different people; so, to avoid any potential operator bias, the measured ewe weights are reported.

Sale lamb/hogget performance is measured by recording for each sale mob; date of sale, numbers sold and average body weight, along with average lamb value (\$) and live weight value $(\phi / \mathrm{kg})$.

\section{Results \& Discussion}

In 2008, the 3532 ewes wintered produced $90.8 \mathrm{t}$ of weaned lamb (Figure 1). By 2018, the 4451 ewes mated produced over $163 \mathrm{t}$ weaned lamb. This $80 \%$ improvement in flock performance has not been linear and shows three distinct periods of change. The first two (2009-2011 and 2012-2015) occurred when the emphasis was on dryland pasture development. The latest (2016-2018) reflects the transfer of the water right to the centre pivot irrigation development. Across

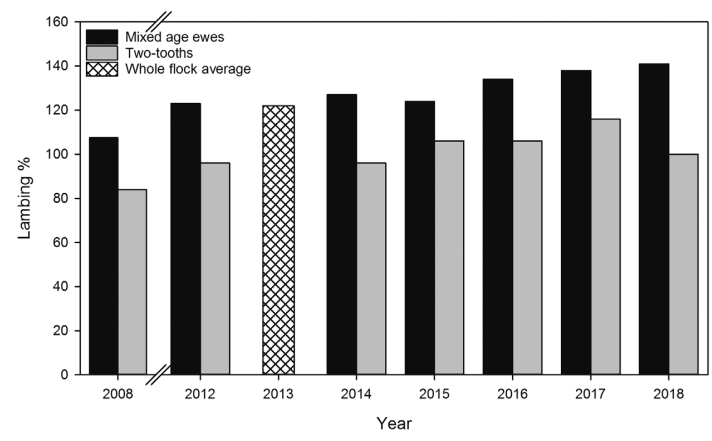

Figure 2 Lambing percentage (\%) of mixed age ewes, twotooths or averaged over the whole flock (2013/14) at Bog Roy Station.

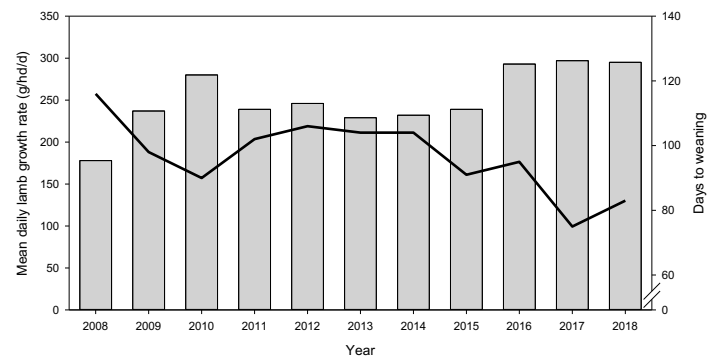

Figure 3 Change in pre-weaning lamb growth rates $(\mathrm{g} / \mathrm{hd} / \mathrm{d}$; bars) and time to weaning (days; line) from 2008 (pre-development) to 2018 at Bog Roy Station.

the time period, there have been many management changes, but integral to all of them has been to understand the legume management required to drive animal production.

\section{Dryland pasture development}

Anderson et al. (2014) outlined the traditional highcountry management reflected for fine wool production in 2008. The bulk of the hill country was set stocked for lambing after a minimal period of spelling and therefore little time for pasture recovery. The mixed age ewes lambed at $107 \%$ with two-tooths at $84 \%$ (Figure 2). The average lamb growth rate was $178 \mathrm{~g} /$ $\mathrm{hd} / \mathrm{d}$ with an average weaning age of 116 days (Figure $3)$. There was some lucerne grazing on 30 ha postweaning by replacement and cull ewe lambs, and wethers, particularly from the flood irrigated paddocks near Lake Benmore.

\section{Period 1: Grazed lucerne}

In the period 2009-2011, there was a step change in lamb production to $\sim 111 \mathrm{t}$ of weaned lamb, from a similar number of ewes, compared with $91 \mathrm{t}$ in 2008 (Figure 1). This increase was associated with greater grazing of the lucerne during the lactation period (Anderson et al. 2014). Paddocks of lucerne ( $\sim 12$ ha) that had previously been used for conservation, were split into six smaller 


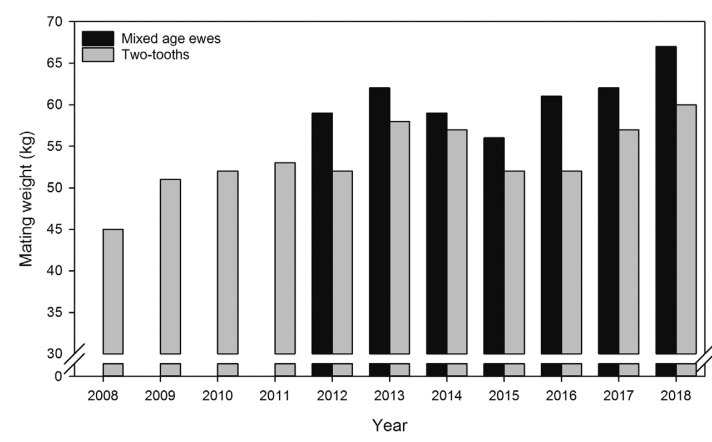

Figure 4 Mating weights $(\mathrm{kg})$ of mixed age ewes and twotooths from 2008 (pre-development) to 2018 at Bog Roy Station.

paddocks with electric fences and rotational grazed with merino ewes and lambs, following strict management rules (Moot et al. 2003). With ewes and lambs on lucerne, pre-weaning lamb growth rates increased from 170 to $\sim 250 \mathrm{~g} / \mathrm{hd} / \mathrm{d}$ and average weaning age was 19 days earlier (Figure 3). By grazing ewes and lambs on lucerne pre-weaning, the hill country was observed to recover with annual legumes able to set seed before the ewes were reintroduced to the hills post-weaning. This change in management has now been implemented for a decade. Observations of the pasture indicate the resident Hieracium pilosella that covered large areas of the hill pre 2008 has now virtually disappeared and has been replaced by taller plants including cluster clover (Trifolium glomeratum), haresfoot clover (T. arvense) and cocksfoot. The improved quantity and quality of feed on the hill country has increased the ewe condition score and weight at mating (Figure 4). During these years, most hoggets were carried through the winter and sold after spring shearing. Two-tooth pre-mating weight increased from $45 \mathrm{~kg}$ to average $52 \mathrm{~kg}$. Heavier mating weights are likely to have increased ovulation rates (Rutherford et al. 2003), which underpin the measured increase in lambing percentage (Figure 2).

\section{Period 2: Increased lambing performance}

The second stepwise lift in the dryland performance was from 2012-2015 with $\sim 130 \mathrm{t}$ weaned lamb (Figure 1). This was driven by an improvement in ewe lambing percentage and reduction in lamb wastage, and their ability to continue to meet a set weaning target weight of $28-29 \mathrm{~kg} / \mathrm{hd}$ after $\sim 100$ days (Figure 3). Mixed age ewe lambing percentage increased from $108 \%$ in 2008 to $\sim 125 \%$ in 2015 (Figure 2) across an additional $10 \%$ more ewes (Figure 1).

The increase in ewe lambing percentage was attributed to improvements in feed management during the mating period (Rutherford et al. 2003). This involved preferential feeding of light ewes and greater use of both lucerne and ryecorn to achieve target mating

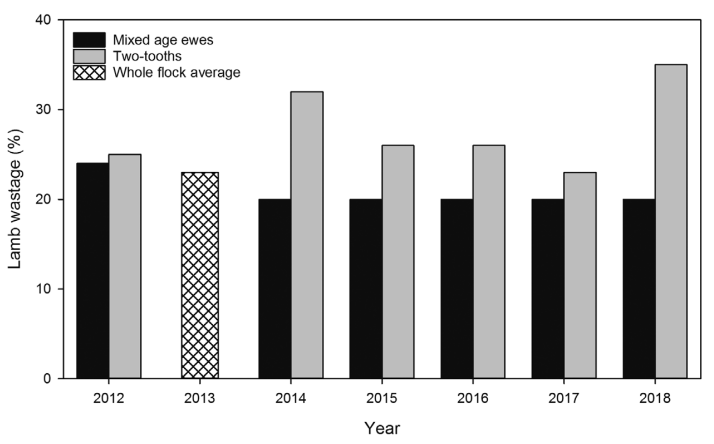

Figure 5 Lamb wastage (\%) of mixed age ewes and twotooths at Bog Roy Station from 2012 to 2018. The whole flock average is reported for 2013.

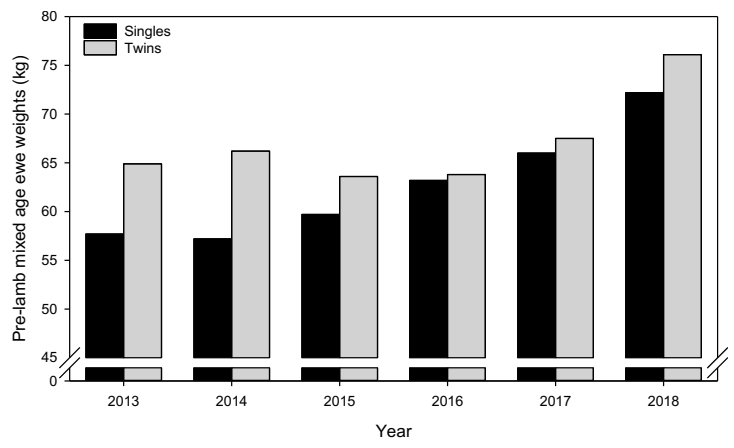

Figure 6 Pre-lambing weights $(\mathrm{kg})$ of mixed age ewes bearing either singles or twins at Bog Roy Station from 2013 to 2018 .

weights of 55 and $60 \mathrm{~kg} / \mathrm{hd}$ for two-tooths and mixed age ewes (Figure 4). Agronomically, this was possible because of the greater understanding of lucerne grazing management, and the expansion of the lucerne area available during lactation and ryecorn for winter feed.

This second period also saw a reduction in lamb wastage from 24 to $20 \%$ (Figure 5) in the mixed age ewes. This improvement occurred in association with preferential feeding of twinning ewes, scanning into lambing dates and further subdivision of paddocks, including identifying paddocks with high and low survival outcomes. A stricter culling policy was also implemented for all dry/dry and wet/dry ewes, and those with defective udders. Increased vaccination for Johnes disease probably also reduced ewe losses. Potentially, the most important driver of improved lamb survival has been their increased condition score and associated pre-lambing weights of these merino ewes prior to set stocking (Figure 6). This highlights their condition at the end of winter which contributes positively to lamb birth weight, udder development, ewe colostrum and milk production and therefore pre-weaning lamb survival and growth (Keynon \& Webby 2007). The combined benefits of these decisions can be seen from the increase in $\mathrm{kg}$ 


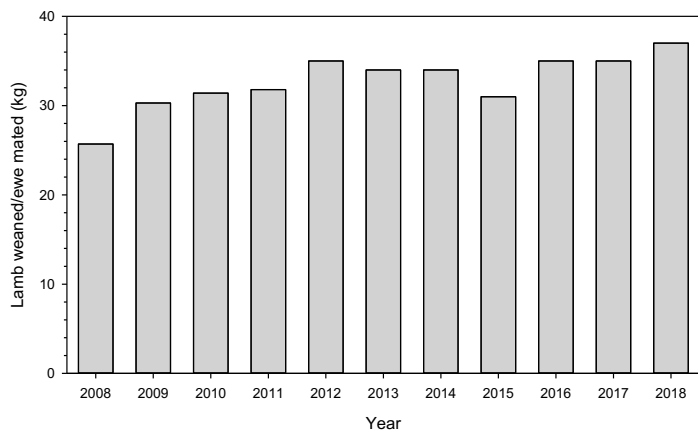

Figure 7 Lamb weaned per ewe mated from 2008 (predevelopment) to 2018 at Bog Roy Station.

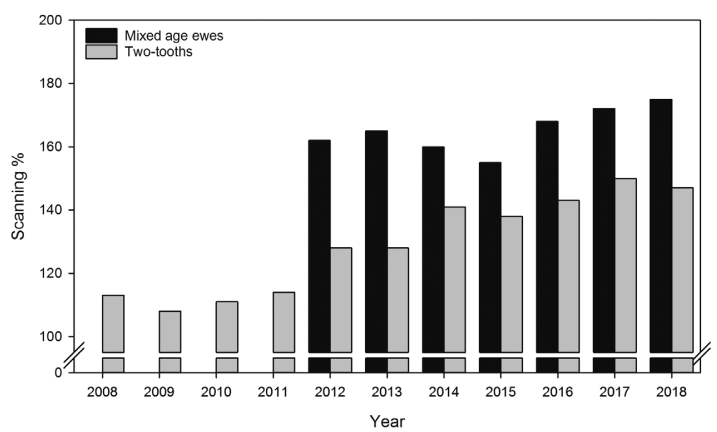

Figure 8 Scanning percentage (\%) of mixed-age ewes and two-tooths from 2008 (pre-development) to 2018 at Bog Roy Station.

lamb weaned per ewe mated from 25 to $32 \mathrm{~kg}$ over the six-year period (Figure 7). Of note was the improved performance of the replacement ewe lambs coming into the flock as two-tooths. This is reflected in their scanning percentage which increased from $113 \%$ in 2008 to an average of $138 \%$ in 2015 (Figure 8), with a consequent increase in lambing from $84 \%$ to $106 \%$, respectively (Figure 2).

During the dryland development, the production of ewe wool remained relatively constant at around $19,000 \mathrm{~kg} / \mathrm{yr}$ (Figure 9). The annual variations in total wool production reflect the earlier selling of some stock, particularly the hoggets which are now sold at a younger age with some unshorn. Cow numbers initially dropped during the dryland development period (Figure 10). However, this was mainly caused by external factors, whereby the cattle have been used to buffer changes in feed supply into the whole farm system. For example, a flat area of 120 ha near the Otamatapaio River (with an agreed grazing capacity of 70 cows per year) was returned to the Crown and fenced off when tenure review was finalised. The change in total feed supply in the dry 2015 year, when irrigation ceased near Lake Benmore before the pivots came on line in 2016, was also buffered by reduced cattle numbers.

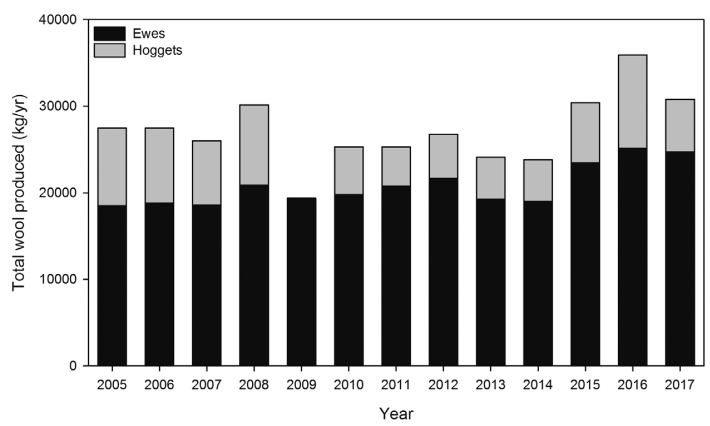

Figure 9 Wool production from ewes and hoggets (kg/yr) at Bog Roy Station from 2005 to 2017.

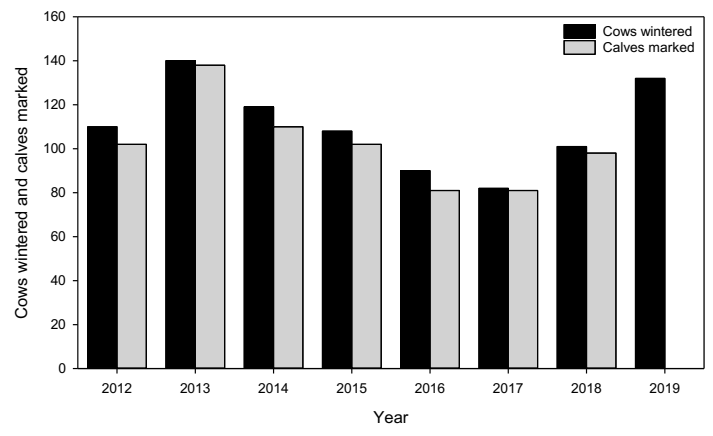

Figure 10 Changes in the number of cows wintered and calves marked at Bog Roy Station between 2012 and 2019.

\section{Period 3: Irrigation development}

The transfer of the water right away from the shores of Lake Benmore enabled a 210-ha centre pivot development. The benefit of the irrigation is visible in the third step change (2016-2018) to over 140 of weaned lamb (Figure 1) before it was fully operational in 2018 when $160 \mathrm{t}$ of weaned lamb was produced. The additional feed available from the pivots means all classes of stock have benefitted. The pre-weaning lamb growth rate increased from 245 to $\sim 290 \mathrm{~g} / \mathrm{hd} / \mathrm{d}$ and weaning is occurring at an average of 80 days (Figure 3 ). The early weaning has allowed the ewes 3-4 weeks longer to recover on the annual legume dominant hills which has increased their condition at mating (Figure 4) and then maintained it during the winter and prior to lambing (Figure 6). Early weaning also reduced the total demand on the high-quality dryland lucerne and red clover (T. pratense) based pastures under the pivots. This reduction meant these high-quality specialist feeds could be prioritised for weaned lambs to maximise post-weaning growth rates. The mixed age ewes are lambing over $140 \%$ (170\% scanning) and two-tooths are around $108 \%$ (147\% scanning) (Figures 2 and 8). The drop in two-tooth lambing back from $116 \%$ in 2017 to $100 \%$ in 2018 is a consequence of lambing them in a new isolated hill block near the pivot where losses from 
human predation appear to have occurred. It will not be used for lambing two-tooths again. Their pre-mating weights in 2018 were $60 \mathrm{~kg}$ and the mixed age ewes were $67 \mathrm{~kg}$ (Figure 4).

Overall, each ewe is now producing $37 \mathrm{~kg}$ weaned lamb which is $44 \%$ higher than in 2008 (Figure 7). The pivots have also provided the opportunity to retain more stock so ewe numbers have increased from 3500 to 4400 and their wool production is now around 25,000 $\mathrm{kg}$ with an additional 6,000 from the hoggets (Figure 9 ). The increased lambing percentage has enabled about $20 \%$ of the ewes to be put to a Romney terminal sire. A percentage of these are sold prime at weaning, while the remainder, along with merino wethers and cull ewe hoggets are gone by autumn after shearing. The average weight for these lambs was $36.3 \mathrm{~kg}$ in 2018. The hill country is now regularly developing high pasture covers in spring and cattle numbers are targeted to increase from 110 to 150 to cope with the additional feed.

Financially, the total revenue from lamb sales, excluding income from wool from shorn lambs or hoggets, has been recorded since 2012. This has increased from $\$ 236,000$ to $\$ 623,000$ (Table 1). Throughout this period, more lambs were being sold earlier so income is also received earlier. The additional value per lamb is in part due to their heavier weights which means more lambs are sold prime, and half-bred and merino ewe lambs are sold at higher prices to other farmers as replacements.

Table 1 Average lamb value ( $\mathrm{kg} / \mathrm{hd}$ ), total income from lambs, average lamb liveweight (LWt) at sale and average LWt value $(\phi / \mathrm{kg})$ between 2012/13 and 2017/18 at Bog Rog Station

\begin{tabular}{|c|c|c|c|c|}
\hline Year & $\begin{array}{c}\text { Average } \\
\text { lamb } \\
\text { value } \\
\text { (\$/hd) }\end{array}$ & $\begin{array}{c}\text { Total } \\
\text { lamb } \\
\text { income } \\
(\$)\end{array}$ & $\begin{array}{c}\text { Average } \\
\text { sale } \\
\text { LWt } \\
\text { (kg) }\end{array}$ & $\begin{array}{c}\text { Average } \\
\text { LWt } \\
\text { value } \\
(c / k g)\end{array}$ \\
\hline $2012 / 13$ & 73.97 & 236,409 & 31.5 & 234 \\
\hline $2013 / 14$ & 69.94 & 238,503 & 29.2 & 239 \\
\hline $2014 / 15$ & 74.12 & 256,911 & 31.6 & 234 \\
\hline $2015 / 16$ & 99.97 & 337,499 & 39.6 & 252 \\
\hline $2016 / 17$ & 117.21 & 436,956 & 39.4 & 297 \\
\hline $2017 / 18$ & 154.78 & 623,074 & 41.5 & 371 \\
\hline
\end{tabular}

\section{Conclusions/Practical implications}

The dryland pasture management changes implemented at Bog Roy Station required the farmers to learn new skills, engage with rural professionals and accept change was necessary to increase production on their farm. The initial changes appear simple in hindsight, but the confidence to change the whole farm system to target legume management was new. The ability to record and document changes in stock performance over time has been invaluable to give the farmers confidence to trust in the process. An additional $70 \mathrm{t}$ of weaned lamb annually and a more resilient farm system provide opportunities for the future that were not considered possible a decade ago.

\section{ACKNOWLEDGEMENTS}

D.J. Moot acknowledges financial support from NZMerino Ltd and Beef + Lamb New Zealand (Hill country - Biodiversity in forage landscapes: Project 18LU01) which enabled this study to be completed.

\section{REFERENCES}

Anderson D, Anderson L, Moot DJ, Ogle GI. 2014. Integrating lucerne (Medicago sativa L.) into a high country merino system. Proceedings of the New Zealand Grassland Association 76: 29-34.

Avery D, Avery F, Ogle GI, Wills BJ, Moot DJ. 2008. Adapting farm systems to a drier future. Proceedings of the New Zealand Grassland Association 70: 1318.

Keynon PR, Webby RW. 2007. Pastures and supplements in sheep production systems. In: Rattray PV, Brookes IM, Nicol AM. Eds. Pastures and supplements for grazing animals. New Zealand Society of Animal Production, Occasional Publication No 14. Pp. 255273.

Moot DJ, Brown HE, Teixeira EI, Pollock KM. 2003. Crop growth and development affect seasonal priorities for lucerne management. New Zealand Grassland Association. Research \& Practice Series No. 11. Pp. 201-208.

Rutherford L, Nicol AM, Logan CM. 2003. Recognising the limits to live weight-reproduction relationships in ewes. Proceedings of the New Zealand Society of Animal Production 63: 140-143. 
